SMALL INTESTINE

\title{
Lysine kinetics in preterm infants: the importance of enteral feeding
}

\author{
S R D van der Schoor, P J Reeds, F Stellaard, J D L Wattimena, P J J Saver, H A Büller, \\ J B van Goudoever
}

See end of article for authors' affiliations .....................

Correspondence to: Dr J B van Goudoever, Erasmus MC-Sophia Children's Hospital, Department of Paediatrics, Division of Neonatology, Dr Molewaterplein 60, $3015 \mathrm{GJ}$, Rotterdam, the Netherlands; i.vangoudoever@ erasmusmc.nl

Accepted for publication 15 April 2003
Introduction: Lysine is the first limiting essential amino acid in the diet of newborns. First pass metabolism by the intestine of dietary lysine has a direct effect on systemic availability. We investigated whether first pass lysine metabolism in the intestine is high in preterm infants, particularly at a low enteral intake. Patients and methods: Six preterm infants (birth weight $0.9(0.1) \mathrm{kg}$ ) were studied during two different periods: period $A(n=6)$ : $40 \%$ of intake administered enterally, 60\% parenterally; lysine intake 92 (6) $\mu \mathrm{mol} /(\mathrm{kg} \times \mathrm{h})$; and period B ( $=4)$ : 100\% enteral feeding; lysine intake 100 (3) $\mu \mathrm{mol} /(\mathrm{kg} \times \mathrm{h})$. Dual stable isotope tracer techniques were used to assess splanchnic and whole body lysine kinetics.

Results: Fractional first pass lysine uptake by the intestine was significantly higher during partial enteral feeding (period A 32 (10)\% v period B 18 (7)\%; $<<0.05)$. Absolute uptake was not significantly different. Whole body lysine oxidation was significantly decreased during full enteral feeding (period A 44 (9) $v$ period B $17(3) \mu \mathrm{mol} /(\mathrm{kg} \times \mathrm{h}) ; \mathrm{p}<0.05)$ so that whole body lysine balance was significantly higher during full enteral feeding (period A 52 (25) $v$ period B 83 (3) $\mu \mathrm{mol} /(\mathrm{kg} \times \mathrm{h}) ; \mathrm{p}<0.05)$.

Conclusions: Fractional first pass lysine uptake was much higher during partial enteral feeding. Preterm infants receiving full enteral feeding have lower whole body lysine oxidation, resulting in a higher net lysine balance, compared with preterm infants receiving partial enteral feeding. Hence parenterally administered lysine is not as effective as dietary lysine in promoting protein deposition in preterm infants.
$\mathrm{T}$ he primed constant intravenous infusion of amino acids labelled with stable isotopes has become the reference method for studying whole body protein dynamics. ${ }^{1-3}$ By measuring oxidation rates of specific amino acids directly, conclusions can be drawn on the excessive supply of a particular amino acid. Because of limitations in studying nutrient metabolism in preterm neonates, several studies in neonatal animals have been performed to quantify protein metabolism in vivo. These studies have shown that the portal drained viscera (intestines, pancreas, spleen, and stomach) utilise more than $50 \%$ of dietary protein intake for protein synthesis and biosynthetic pathways, ${ }^{4-7}$ and is a major site of lysine oxidation. ${ }^{8}$ Of particular importance is the utilisation rate by the intestine of essential amino acids. A high utilisation rate of essential amino acids by the intestine results in lower systemic availability of essential amino acids. We were specifically interested in lysine, which is the first limiting amino acid in milk fed mammalian newborns. ${ }^{9}$ Thus if the amount of protein in the diet is not adequate, the rate of protein synthesis and growth will be determined by the amount of lysine.

The neonatal piglet is generally considered to be a good model for the human infant with respect to rate and pattern of gastrointestinal tract development. ${ }^{10}$ In addition, amino acid patterns are similar between piglets and infants in terms of both plasma concentrations and requirements. ${ }^{11}{ }^{12}$ However, there are no data on lysine kinetics in infants while in adults splanchnic lysine uptake has been found to vary between $5 \%$ and $35 \%$ of lysine intake. ${ }^{73}$

Largely as a result of their immature gastrointestinal tract, all preterm infants face a period of compromised enteral intake in their first weeks of life, and they frequently receive a combined parenteral and enteral nutrient supply. Based on our finding that absolute lysine utilisation by the intestine of neonatal pigs appears to be independent of lysine intake, ${ }^{8}$ we postulated that fractional first pass lysine utilisation would be much higher during a restricted enteral intake. Importantly, this would result in a lower systemic availability of dietary lysine. Therefore, we measured first pass lysine uptake in response to two different enteral intakes in neonates.

Apart from first pass lysine utilisation, the magnitude of intestinal lysine catabolism is also important to the nutrition of preterm newborns. The energy needed to sustain the high rate of protein turnover in the gut is largely derived from oxidation of non-essential amino acids. ${ }^{4}{ }^{14}$ However, some essential amino acids, including lysine, are also oxidised, which leads to irreversible loss. ${ }^{8}{ }^{15}{ }^{16}$ Despite the general belief that the intestinal mucosa does not possess lysine catabolic enzymes, ${ }^{17}{ }^{18}$ we showed that intestinal oxidation of dietary lysine in pigs accounted for approximately $30 \%$ of whole body lysine oxidation. ${ }^{6}$ Whether dietary lysine is oxidised by splanchnic tissues in humans has not yet been investigated. Quantification of the response of splanchnic and whole body lysine oxidation on the level of enteral protein intake in preterm infants was the second objective of this study.

\section{METHODS}

\section{Patients}

The study protocol was approved by the Erasmus University Institutional Review Board. Written informed consent was obtained from parents. Splanchnic and whole body lysine kinetics were quantified in preterm infants during partial enteral feeding (period A) and full enteral feeding (period B). Patients eligible for this study were premature infants with a birth weight ranging from $750 \mathrm{~g}$ to $1250 \mathrm{~g}$ who were appropriate for gestational age according to the charts of

Abbreviations: LRP, lysine release from protein breakdown; NOLD, non-oxidative lysine disposal; PDB, Pee Dee Belemnite 


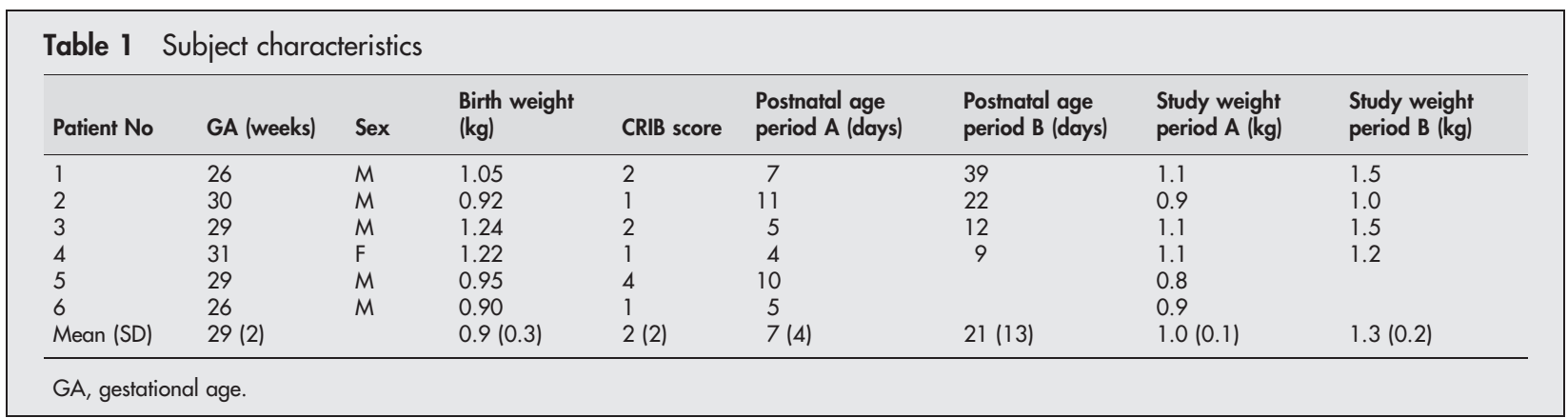

Usher and McLean. ${ }^{19}$ Excluded from the study were infants who had congenital anomalies, or gastrointestinal or liver diseases. CRIB scores ${ }^{20}$ on the first day of life were all below 5. The clinical characteristics of the neonates are shown in table 1 . They received a nutrient regimen according to our feeding protocol: a combination of breast feeding or formula (Nenatal; Nutricia, Zoetermeer, the Netherlands) and parenteral nutrition containing glucose, amino acids (Primene 10\%; Clintec Benelux NV, Brussels, Belgium), and lipids (Intralipid 20\%; Fresensius Kabi, Den Bosch, the Netherlands). Nenatal was given as sole enteral nutrition 12 hours before the start of the study and during the study days.

\section{Protocol}

The study design consisted of two periods of two consecutive study days (period A-study days 1 and 2, and period Bstudy days 3 and 4) (fig 1). During period A, infants received $40 \%$ enteral and $60 \%$ parenteral feeding, and during period $\mathrm{B}$ they received full enteral feeding. During period A, infants were implanted with both an arterial and intravenous catheter for infusion of tracers and withdrawal of blood samples. During period B, a peripheral intravenous catheter was available for infusion of tracers; blood samples were collected by heelstick. Withdrawing blood via a heelstick is obtaining blood from arterial capillaries while the heel is heated before collection to ensure easy collection. We assume that similar to the heated hand box technique, there is no difference in plasma enrichment. ${ }^{21}$

In order to collect breath samples from these infants, we used the method described by Perman et al who used a nasal tube..$^{22}$ This method has been used in children ${ }^{22}$ and preterm infants for collection of expiratory $\mathrm{CO}_{2}$ recovery after administration of ${ }^{13} \mathrm{C}$ labelled substrates. ${ }^{23}{ }^{24}$ We have validated this technique for the use of oxidation studies in preterm infants (Van der Schoor, unpublished data). Briefly, a 6 Fr gastric tube (6 Ch Argyle; Sherwood Medical, Tullamore, Ireland) was placed $1-1.5 \mathrm{~cm}$ into the nasopharynx, and a sample of $15 \mathrm{ml}$ end tidal breath was taken slowly with a syringe. Duplicate aliquots of expired air from each sampling point were stored in vacutainers for analysis.

Three different stable isotope infusions were performed during each study day. Firstly, a primed two hour infusion $(10.02 \mu \mathrm{mol} / \mathrm{kg}$ and $10.02 \mu \mathrm{mol} /(\mathrm{kg} \times \mathrm{h}))$ of $\left[{ }^{13} \mathrm{C}\right]$ bicarbonate
Study day 1

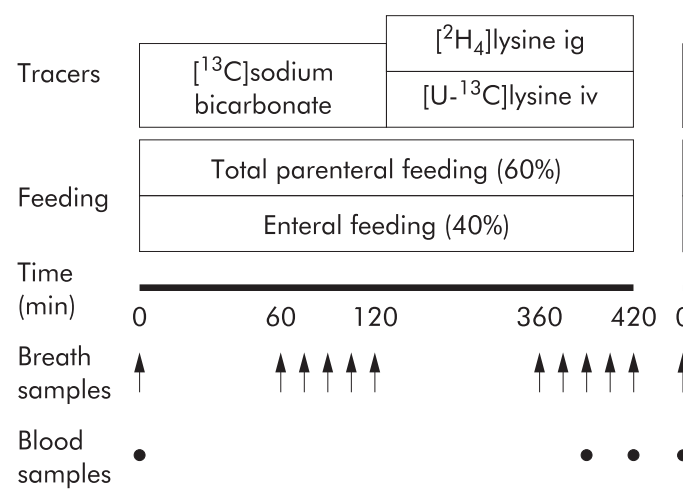

Study day 3

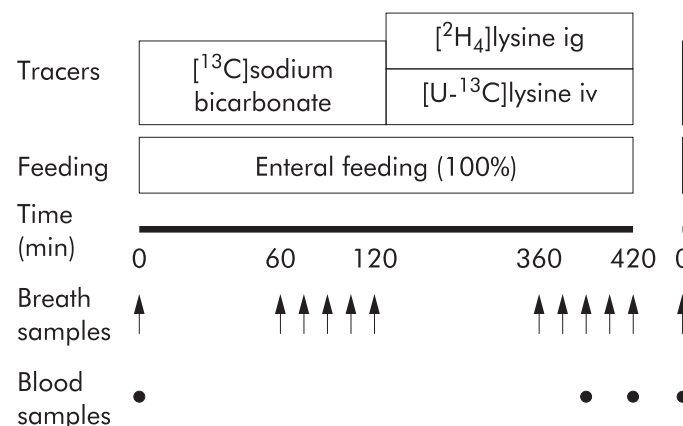

Study day 2

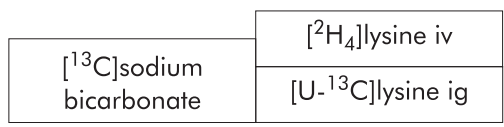

\begin{tabular}{|c|}
\hline Total parenteral feeding $(60 \%)$ \\
\hline Enteral feeding $(40 \%)$ \\
\hline
\end{tabular}

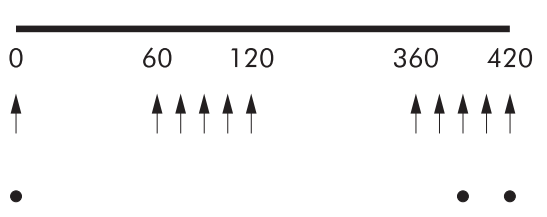

Study day 4

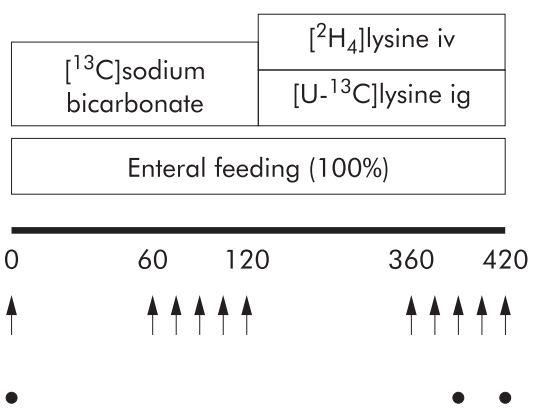

Figure 1 Schematic overview of study days 1 and 2 during period A, and study days 3 and 4 during period B. 
(99.0 mol\% ${ }^{13} \mathrm{C}$; Cambridge Isotopes, Woburn, Massachusetts, USA) dissolved in sterile saline was administered at a constant rate. The ${ }^{13} \mathrm{C}$ labelled bicarbonate infusion was immediately followed by two primed five hour infusions $(9.77 \mu \mathrm{mol} / \mathrm{kg}$ and $9.77 \mu \mathrm{mol} /(\mathrm{kg} \times \mathrm{h}))$ of $\left[\mathrm{U}-{ }^{13} \mathrm{C}\right] \mathrm{lysine}$ (97.0 mol\% ${ }^{13} \mathrm{C}$; Cambridge Isotopes) and $(9.31 \mu \mathrm{mol} / \mathrm{kg}$ and $9.31 \mu \mathrm{mol} /(\mathrm{kg} \times \mathrm{h}))$ of $\left[{ }^{2} \mathrm{H}_{4}\right]$ lysine $\left(98.0 \mathrm{~mol} \%{ }^{2} \mathrm{H}\right.$; Cambridge Isotopes). During both periods $\mathrm{A}$ and $\mathrm{B}$, we administered the tracers in the following order: on study days $\mathrm{l}$ and 3, $\left[\mathrm{U}-{ }^{13} \mathrm{C}\right]$ lysine was given via an intravenous catheter and $\left[{ }^{2} \mathrm{H}_{4}\right]$ lysine via the intragastric catheter; on study days 2 and 4 , the intravenous and intragastric routes were switched. All isotopes were tested and found to be sterile and pyrogen free before use in our studies. At time 0, baseline blood and breath samples were collected. During the last hour of each tracer infusion, breath samples were collected at 15 minute intervals and blood samples were obtained at 390 and 420 minutes. The total amount of blood withdrawn during a study day was $1.5 \mathrm{ml}$, which is less than $2 \%$ of blood volume in a $1000 \mathrm{~g}$ infant. Blood was centrifuged immediately and stored at $-70^{\circ} \mathrm{C}$ for further analysis.

\section{Analytical methods}

Small aliquots of plasma $(100 \mu \mathrm{l})$ were taken for measurement of plasma lysine concentrations by an Amino Acid Analyser (Biochrom Ltd, Cambridge, UK). Enrichment of $\left[\mathrm{U}-{ }^{13} \mathrm{C}\right]$ lysine and $\left[{ }^{2} \mathrm{H}_{4}\right]$ lysine in plasma was determined by gas chromatography-mass spectrometry as the $\mathrm{N}(\mathrm{O}, \mathrm{S})$ methoxycarbonylmethylester derivative according to Husek, ${ }^{25}$ with minor modifications. Breath samples were analysed for enrichment of ${ }^{13} \mathrm{CO}_{2}$ on an isotope ratio mass spectrometer (ABCA; Europa Scientific, Van Loenen Instruments, Leiden, the Netherlands). ${ }^{26}$

\section{Calculations}

The rate of lysine turnover was calculated by measuring tracer dilution at steady state as modified for stable isotope tracers, as previously described. ${ }^{27}{ }^{28}$ The equations used to obtain the results are detailed in the appendix.

\section{Statistics}

Data are expressed as mean (SD) values obtained from samples taken over the last hour of each tracer infusion. Statistical comparisons were performed using the Student's $t$ test. A value of $\mathrm{p}<0.05$ was taken as statistically significant.

\section{RESULTS}

Six patients were studied during period A and four during period B (table 1). Body weight at the time of period A was
$1.0(0.1) \mathrm{kg}$ and $1.3(0.2) \mathrm{kg}$ during period B. All infants were clinically stable with no clinical signs of septicaemia. Routine blood chemistry and haematology were all within normal limits, and there were no significant changes in these parameters 24 hours before and after the study. During period A, five of six infants received supplemental oxygen by a nasal prong, while during period B none of the four infants needed supplemental oxygen. Mean lysine, protein, glucose, fat, and energy intakes during periods $\mathrm{A}$ and $\mathrm{B}$ are presented in table 2.

\section{Isotopic plateau}

Lysine kinetics were calculated from the plateau enrichment values for plasma lysine and breath carbon dioxide (table 3 ). Background recovery of the $\left[{ }^{13} \mathrm{C}\right]$ label in expiratory air was not significantly different between both periods (period A $-19.80(1.28) v$ period $\mathrm{B}-20.24(0.99){ }^{13} \mathrm{C}$ Pee Dee Belemnite (PDB)). There was also no difference in background recovery of the $\left[{ }^{13} \mathrm{C}\right]$ label in expiratory air between the two consecutive study days of each period (A: day 1: -20.61 (1.23) $v$ day 2: -18.99 (1.43) PDB; and B: day 1 : $-21.58(0.35) v$ day 2: -18.89 (2.59) PDB). Although we took two blood samples after four hours of tracer infusion, we are sure that steady state was reached as we found an isotopic plateau in $\mathrm{CO}_{2}$ excretion. Before a plateau in breath is reached, a plateau has to be reached at the site of lysine oxidation (that is, intracellularly). ${ }^{13} \mathrm{CO}_{2}$ enrichment in breath during $\left[{ }^{13} \mathrm{C}\right]$ sodium bicarbonate infusion rose rapidly during the first hour of infusion in both periods, to become constant in all infants by 120 minutes, with $<5 \%$ variation in the plateau (period A 4.1 (1.0) $v$ period B $3.4(0.8) \%$ ). The coefficient of variation of breath $\left[{ }^{13} \mathrm{C}\right]$ lysine enrichment above baseline at plateau was 6.2 (1.5)\% during period A and 6.8 ( 1.6$) \%$ during period $\mathrm{B}$.

\section{Lysine kinetics}

Plasma lysine concentration was significantly higher during partial enteral feeding compared with full enteral feeding (period A $231 \quad(108) \quad v$ period B 133 (48) $\mu \mathrm{mol} /(\mathrm{kg} \times \mathrm{h})$; $\mathrm{p}<0.05)$. As expected, whole body lysine fluxes were higher for the oral than for the intravenous tracer group during both periods (period A flux intragastric 396 (49) $v$ flux intravenous $267(35) \mu \mathrm{mol} /(\mathrm{kg} \times \mathrm{h})$; period B flux intragastric 279 (42) $v$ flux intravenous 231 (40) $\mu \mathrm{mol} /(\mathrm{kg} \times \mathrm{h}))$. First pass lysine uptake as a fraction of dietary lysine intake was significantly higher during restricted enteral lysine intake (period A 32 (10) $v$ period B $18(7) \% ; \mathrm{p}<0.05)$. However, splanchnic lysine uptake in absolute amounts was not significantly different during full enteral intake (period A 10 (3) $v$ period B 18

\begin{tabular}{lcc} 
Table 2 Lysine, protein, carbohydrate, fat, and energy intakes during periods A and B \\
\hline & Period A & Period B \\
\hline Total lysine intake $(\mu \mathrm{mol} /(\mathrm{kg} \times \mathrm{h}))$ & $92(13)$ & $100(6)$ \\
Enteral & $33(5)$ & $100(6)$ \\
Parenteral & $59(15)$ & - \\
Total protein intake $(\mathrm{g} /(\mathrm{kg} \times$ day $))$ & $3.4(0.3)$ & $3.5(0.2)$ \\
Enteral & $1.2(0.2)$ & $3.5(0.2)$ \\
Parenteral & $2.2(0.6)$ & - \\
Total carbohydrate intake $(\mathrm{g} /(\mathrm{kg} \times$ day)) & $10.6(2.2)$ & $11.5(0.7)$ \\
Enteral & $3.7(0.6)$ & $11.5(0.7)$ \\
Parenteral & $6.9(2.0)$ & - \\
Total fat intake $(\mathrm{g} /(\mathrm{kg} \times$ day $))$ & $4.1(0.9)^{*}$ & $6.5(0.4)$ \\
Enteral & $2.0(0.3)$ & $6.5(0.4)$ \\
Parenteral & $2.0(0.9)$ & - \\
Total energy intake $(\mathrm{kcal} /(\mathrm{kg} \times$ day $))$ & $92(11)^{*}$ & $123(4)$ \\
Enteral & $38(7)$ & $123(4)$ \\
Parenteral & $52(10)$ & - \\
\hline
\end{tabular}

Values are means $(S D) ; n=6$ in period $A$ and $n=4$ in period $B$. ${ }^{*} \mathrm{p}<0.05$. 
Table 3 Baseline and steady state plasma isotopic enrichments on study days 1 and 2 during period $A$ and on study days 3 and 4 during period $B$

\begin{tabular}{|c|c|c|c|c|}
\hline \multirow{3}{*}{$\begin{array}{l}\text { Study } \\
\text { day }\end{array}$} & \multicolumn{2}{|l|}{$\left[\mathrm{U}-{ }^{13} \mathrm{C}\right]$ lysine } & \multicolumn{2}{|l|}{$\left[{ }^{2} \mathrm{H}_{4}\right]$ lysine } \\
\hline & Baseline & Plateau & Baseline & Plateau \\
\hline & (mol\%) & (mol\%) & (mol\%) & (mol\%) \\
\hline 1 & $0.0010(0.0006)$ & $0.0345(0.0042)$ & $0.0019(0.0008)$ & $0.0201(0.0045)$ \\
\hline 2 & $0.0019(0.0007)$ & $0.0315(0.0040)$ & $0.0042(0.0019)$ & $0.0360(0.0067)$ \\
\hline 3 & $0.0018(0.0005)$ & $0.0372(0.0100)$ & $0.0028(0.0008)$ & $0.0324(0.0061)$ \\
\hline 4 & $0.0059(0.0065)$ & $0.0362(0.0074)$ & $0.0031(0.0005)$ & $0.0461(0.0094)$ \\
\hline
\end{tabular}

(6) $\mu \mathrm{mol} /(\mathrm{kg} \times \mathrm{h}) ; \mathrm{p}=0.17)$. Splanchnic tissues did not oxidise dietary lysine during partial enteral feeding or during full enteral feeding (period A -4 (23) $v$ period $\mathrm{B}-18$ (20) $\mathrm{mol} /(\mathrm{kg} \times \mathrm{h}))$.

Whole body lysine oxidation was significantly lower during full enteral feeding (fig 2). Whole body lysine oxidation accounted for 50 (19)\% of total lysine intake during partial enteral nutrition whereas only 17 (3)\% of total lysine intake was oxidised during full enteral feeding $(p<0.05)$. The nonoxidative disposal of lysine (NOLD; period A 222 (36) $v$ period B $169(36) \mu \mathrm{mol} /(\mathrm{kg} \times \mathrm{h}))$ and lysine release of protein breakdown (LRP; period A 214 (39) $v$ period B 131 (38) $\mu \mathrm{mol} /(\mathrm{kg} \times \mathrm{h}))$ were not significantly different during both periods. The resulting net lysine balance was significantly higher during full enteral feeding (fig 2).

\section{DISCUSSION}

The main purpose of this study was to measure lysine kinetics in preterm infants to gain insight into the importance of splanchnic tissues in relation to whole body lysine kinetics. In addition, we wished to quantify first pass lysine metabolism during both full enteral feeding and significantly lower enteral intake. Our data demonstrated that in preterm infants receiving full enteral feeding, whole body lysine oxidation was significantly lower and lysine balance significantly higher than in preterm infants receiving partial enteral feeding. Approximately one third of dietary lysine is removed by the splanchnic region during partial enteral feeding compared with a lower fraction (18\%) during full enteral feeding. Furthermore, we could not detect any first pass lysine oxidation by splanchnic tissues in either feeding period.
It is of interest to note our results in neonatal pigs receiving a low protein diet, ${ }^{6}$ with regard to the high fractional first pass lysine uptake observed under a restricted enteral amino acid supply in preterm infants. The high splanchnic extraction as a fraction of dietary intake in preterm infants receiving partial enteral feeding is also consistent with the high values for protein turnover observed in immature rats, ${ }^{29}$ with a maximal contribution of the intestine to whole body protein synthesis attained at weaning.

A high first pass uptake may also be caused by incomplete digestion and absorption of dietary proteins and amino acids. However, studies in adults and infants have shown a high digestibility of approximately $98 \%$ of milk proteins and cereal protein. ${ }^{3031}$ This indicates that probably all dietary milk proteins are absorbed by the intestinal mucosa and are not lost in faeces. Thus lysine that does not appear in the systemic circulation is utilised by the intestine, and is not lost via faeces. Indeed, Stoll et al have demonstrated in neonatal pigs that splanchnic tissues have high requirements for amino acids and are proving to be an important modulator of whole body amino acid availability. ${ }^{6}$ High splanchnic lysine extraction in preterm infants in their first weeks of life may be necessary to provide amino acids for their high intestinal protein synthesis during a period of rapid adaptation to enteral feeding. It is well known, for example, that the presence of nutrients in the intestinal lumen provides a marked stimulus to intestinal growth. ${ }^{32}$

In contrast with our finding in piglets, intraluminal lysine or lysine taken up by splanchnic tissues is apparently not oxidised, implying that intestinal lysine metabolism in preterm infants only includes protein synthesis. In other words, these results suggest that the premature gut has a
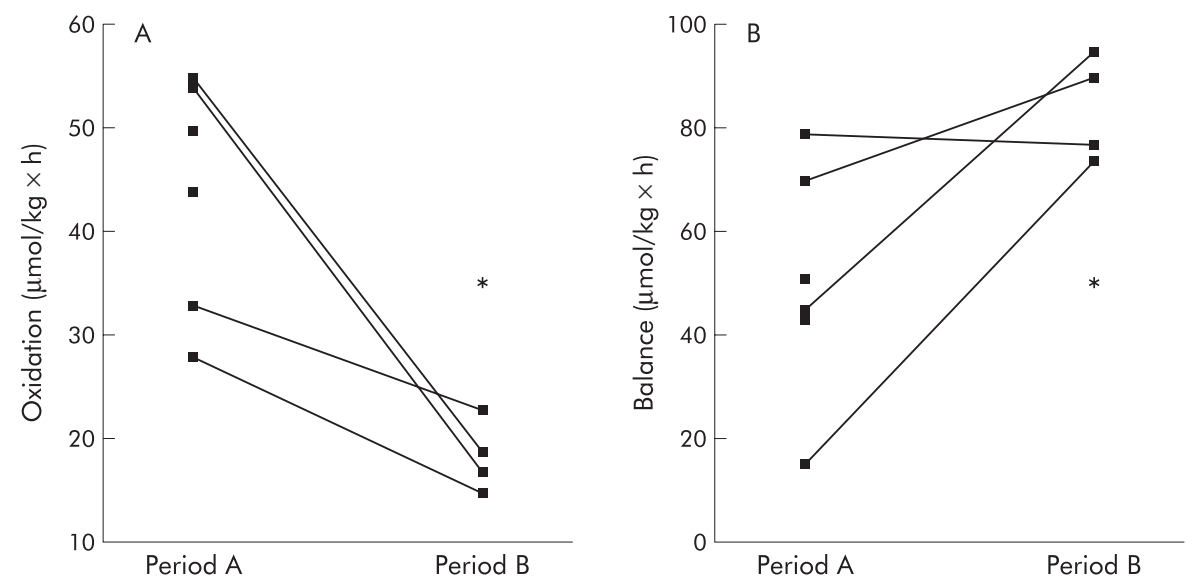

Figure 2 Whole body lysine oxidation and balance in absolute amounts during period $A(n=6)$ and period $B(n=4) .{ }^{*} p<0.05$. 
most efficient use of the essential amino acid lysine, and plays an important role in channelling dietary amino acids to peripheral tissues.

Our second aim was to determine whole body lysine kinetics in relation to two different enteral lysine supplies. Surprisingly, in preterm infants on full enteral feeding, whole body lysine oxidation was significantly lower in comparison with partial enteral feeding. Decreased whole body lysine oxidation suggests a protein sparing mechanism during full enteral feeding in preterm infants. Consequently, lysine balance increased significantly as dietary lysine intake was augmented. In concordance with these oxidation results, plasma lysine concentration was significantly higher during partial enteral feeding. During this feeding period, amino acids were administered via both the venous circulation and the stomach, in contrast with full enteral feeding. The higher plasma lysine concentration during partial enteral feeding may be a result of our direct intravenous infusion and significantly lower first pass lysine uptake by the gut. In addition, lower whole body lysine oxidation during partial enteral feeding may have contributed to a higher plasma lysine level. Another explanation for this observation may be that total amino acid intake was nutritionally better balanced during full enteral feeding, which resulted in an improved lysine balance. In other words, it might indicate that lysine is not the first limiting essential amino acid in the diet under the conditions of partial enteral feeding. Otherwise, lysine oxidation would have been lower during partial enteral feeding.

The apparent lower whole body lysine oxidation and higher lysine balance during full enteral feeding were similar to values obtained by Duffy and Pencharz. ${ }^{33}$ Their study compared the effect of feeding route (intravenous or enteral) on protein metabolism of the neonate and concluded that orally fed neonates utilise amino acids for synthesis more efficiently than total parenterally fed infants. ${ }^{33}$ Early parenteral supply of amino acids is given to prevent protein loss but the present study clearly shows that enteral feeding is a far more efficient way of feeding preterm infants. Unfortunately, intestinal immaturity often impairs early full enteral feeding but our data suggest that maximal effort should be paid to initiate enteral feeding as soon as possible in preterm infants. ${ }^{34}$

There were some limitations in our study design. Energy intake is one of the factors that influence protein synthesis rate. Although lysine intakes during both feeding periods were almost identical, energy intake was significantly different between the feeding periods. Intake of metabolic energy by partial enterally fed infants was $74 \%$ of the intake of enterally fed infants. Parenterally fed neonates appear to require only $75 \%$ of the energy of enterally fed infants to achieve the same growth rate ${ }^{35}$ because of the lower energy expenditure of the splanchnic tissues during parenteral nutrition. In addition, enterally fed infants have some energy losses in stool due to malabsorption. In a previous study, we found no significant effect of reducing energy intake from 120 to $100 \mathrm{kcal} /(\mathrm{kg} \times$ day $)$ on nitrogen excretion and protein deposition in preterm infants. ${ }^{36}$ Van Goudoever et al showed in preterm infants that the overall pattern of fuel utilisation was unaffected by the mode of feeding. ${ }^{37}$ Therefore, we speculate that the higher energy intake during full enteral feeding did not significantly influence lysine kinetics.

Another issue relevant to the study design is the different postnatal ages at both study periods. Infants were older during period B, which may have influenced lysine kinetics. However, it was not feasible in our study design to have infants on full enteral feeding on day 7. On the other hand, it was not ethically justified to have infants on partial enteral feeding at a postnatal age of three weeks for a period of at least five days in order for them to adjust to a reduced enteral feeding rate. In addition, we wanted to evaluate lysine kinetics in preterm infants who were treated according to standard neonatal intensive care feeding regimens.

In conclusion, we have shown that splanchnic tissues have a high rate of metabolism and use almost one third of dietary lysine intake in preterm infants undergoing partial enteral feeding. However, although lysine is catabolised by the whole body to a great extent, especially during partial enteral feeding, it is not catabolised by splanchnic tissues during first pass in preterm infants. Furthermore, lysine balance was much higher during full enteral feeding compared with partial enteral feeding. Taken together, the results indicate that parenterally administered lysine is not as effective as dietary administered lysine in promoting protein deposition in preterm infants in their first weeks of life.

\section{ACKNOWLEDGEMENTS}

The Sophia Foundation of Scientific Research (Kröger Foundation) and the Royal Netherlands Academy of Arts and Science (Ter Meulen Fund) supported this work. We thank J Francke for laboratory analysis. We thank Professor Dr D Tibboel for helpful comments and review of the manuscript.

\section{Authors' affiliations}

S R D van der Schoor, J D L Wattimena, H A Büller, Erasmus MCSophia Children's Hospital, Department of Paediatrics, Dr Molewaterplein 60, 3015 GJ, Rotterdam, the Netherlands F Stellaard, P J J Sauer, University Hospital Groningen, Department of Paediatrics, Hanzeplein 1, 9713 GZ Groningen, the Netherlands J B van Goudoever, Erasmus MC-Sophia Children's Hospital, Department of Paediatrics, Dr Molewaterplein 60, 3015 GJ, Rotterdam, the Netherlands, and USDA/ARS Children's Nutrition Research Centre, Department of Paediatrics, Baylor College of Medicine, 1100 Bates St, Houston, TX, 77030, USA

This paper is dedicated to the memory of P J Reeds. His passing in late 2002 represented an enormous loss for everyone who had the privilege of working with him. Dr Reeds was a great mentor and noble role model, who continues to provide inspiration to his former colleagues.

\section{APPENDIX}

Lysine flux was calculated as:

$$
\mathrm{Q}_{\mathrm{iv}}=\mathrm{i}_{\mathrm{L}} \times\left[\left(\mathrm{E}_{\mathrm{i}} / \mathrm{E}_{\mathrm{p}}\right)-\mathrm{l}\right]
$$

where $\mathrm{Q}_{\mathrm{iv}}$ is flux of the intravenous lysine tracer $(\mu \mathrm{mol} /$ $(\mathrm{kg} \times \mathrm{h})), \mathrm{i}_{\mathrm{L}}$ is the lysine infusion rate $\left.(\mu \mathrm{mol} / \mathrm{kg} \times \mathrm{h})\right)$, and $\mathrm{E}_{\mathrm{i}}$ and $\mathrm{E}_{\mathrm{p}}$ are the enrichments (mol\% excess) of $\left[\mathrm{U}_{-}{ }^{13} \mathrm{C}\right.$ or $\left.{ }^{2} \mathrm{H}_{4}\right]$ lysine in the lysine infusate and in plasma at steady state, respectively.

First pass lysine uptake was calculated as:

$$
\mathrm{U}=\left[\left(\mathrm{Q}_{\mathrm{ig}}-\mathrm{Q}_{\mathrm{iv}}\right) / \mathrm{Q}_{\mathrm{ig}}\right] \times \mathrm{I}
$$

where $\mathrm{U}$ is first pass lysine uptake $(\mu \mathrm{mol} /(\mathrm{kg} \times \mathrm{h}))$, $\mathrm{Q}_{\mathrm{ig}}$ is flux of the intragastric lysine tracer $(\mu \mathrm{mol} /(\mathrm{kg} \times \mathrm{h}))$, and $\mathrm{I}$ is enteral lysine intake $(\mu \mathrm{mol} /(\mathrm{kg} \times \mathrm{h}))$.

At steady state, the amount of lysine entering the plasma pool should be equal to the amount of lysine leaving the pool. Lysine can enter the pool either by being released from proteins as result of breakdown or through diet. Lysine leaving the pool may be either oxidative disposal or nonoxidative disposal.

$$
\mathrm{Q}=\mathrm{I}+\mathrm{LRP}=\mathrm{Ox}+\mathrm{NOLD}
$$

where Q is flux of the lysine tracer $(\mu \mathrm{mol} /(\mathrm{kg} \times \mathrm{h}))$, LRP is the amount of lysine released from protein via protein breakdown $(\mu \mathrm{mol} /(\mathrm{kg} \times \mathrm{h})), \mathrm{Ox}$ is the rate of lysine oxidation $(\mu \mathrm{mol} /(\mathrm{kg} \times \mathrm{h}))$, and NOLD is the rate of non-oxidative lysine disposal $(\mu \mathrm{mol} /(\mathrm{kg} \times \mathrm{h}))$. 
Net lysine balance, an index of protein deposition, was calculated as:

$$
\mathrm{B}=\mathrm{NOLD}-\mathrm{LRP}
$$

where $\mathrm{B}$ is lysine balance $(\mu \mathrm{mol} /(\mathrm{kg} \times \mathrm{h}))$.

Whole body $\mathrm{CO}_{2}$ production was estimated as:

$$
\text { Body } \mathrm{CO}_{2} \text { production }=\mathrm{i}_{\mathrm{B}} \times\left[\left(\mathrm{E}_{\mathrm{iB}} / \mathrm{IE}_{\mathrm{B}}\right)-1\right]
$$

where $i_{B}$ is the infusion rate of $\left[{ }^{13} \mathrm{C}\right]$ sodium bicarbonate $(\mu \mathrm{mol} /(\mathrm{kg} \times \mathrm{h})), \quad \mathrm{E}_{\mathrm{iB}}$ is enrichment (mol\% excess) of $\left[{ }^{13} \mathrm{C}\right]$ bicarbonate in the bicarbonate infusate and $\mathrm{IE}_{\mathrm{B}}$ is ${ }^{13} \mathrm{CO}_{2}$ enrichment at plateau during the $\left[{ }^{13} \mathrm{C}\right]$ sodium bicarbonate infusion (mol\% excess). This equation does not correct for retention of $\left[{ }^{13} \mathrm{C}\right]$ bicarbonate in different body pools and will overestimate $\mathrm{CO}_{2}$ production rate. However, the same correction factor has to be applied to quantify the lysine oxidation rate (eqn (6)). Consequently, lysine oxidation rate is not overestimated. ${ }^{38}$

As described previously, lysine oxidation was calculated by multiplying recovery of $\left[{ }^{13} \mathrm{C}\right]$ lysine in expiratory air with the rate of appearance of lysine. ${ }^{38}$ The fraction of lysine oxidised was measured according to the following equation, assuming a constant $\mathrm{VCO}_{2}$ (rate of $\mathrm{CO}_{2}$ production) during the study, that lasted seven hours ${ }^{38}$ :

Fraction of lysine oxidised $=\left[\operatorname{IE}_{\mathrm{L}} \times \mathrm{i}_{\mathrm{B}}\right] /\left[\mathrm{IE}_{\mathrm{B}} \times \mathrm{i}_{\mathrm{L}} \times 6\right]$

where $\mathrm{IE}_{\mathrm{L}}$ and $\mathrm{IE}_{\mathrm{B}}$ are ${ }^{13} \mathrm{CO}_{2}$ enrichments (mol\% excess) at steady state during intravenous $\left[\mathrm{U}-{ }^{13} \mathrm{C}\right]$ lysine and $\left[{ }^{13} \mathrm{C}\right.$ ]bicarbonate infusion. The $\mathrm{i}_{\mathrm{L}}$ is multiplied by a factor of 6 to account for the number of $\mathrm{C}$ atoms that are labelled.

Whole body lysine oxidation was then calculated as:

Whole body lysine oxidation = eqn (6) xeqn (1)

Calculation of the metabolism of enterally administered $\left[\mathrm{U}-{ }^{13} \mathrm{C}\right]$ lysine to $\mathrm{CO}_{2}$ is complicated by the fact that some of the lysine tracer is absorbed and thereby labels the arterial pool. Thus the non-first pass oxidation of $\left[{ }^{13} \mathrm{C}\right]$ labelled lysine that was administered enterally but was absorbed and entered the body at study day 2 can be calculated as:

Non-first pass oxidation of enterally administered

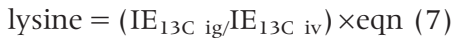

where $\mathrm{IE}_{13 \mathrm{C} \text { ig }}$ is the ${ }^{13} \mathrm{C}$ enrichment (mol\% excess) in plasma during intragastric $\left[{ }^{13} \mathrm{C}\right]$ lysine infusion on study day 2 , and $\mathrm{IE}_{13 \mathrm{C}}$ iv is the ${ }^{13} \mathrm{C}$ enrichment in plasma during intravenous $\left[{ }^{13} \mathrm{C}\right]$ lysine infusion on study day 1 .

Total lysine oxidation on study day 2 is calculated as described previously:

Total lysine oxidation $=$ Recovery $($ eqn $(6)) \times \mathrm{Q}_{\mathrm{iv}}$

where $Q_{\text {iv }}$ is the flux of the intravenous $\left[{ }^{2} \mathrm{H}_{4}\right]$ lysine tracer $(\mu \mathrm{mol} /(\mathrm{kg} \times \mathrm{h}))$.

First pass lysine oxidation can thus be calculated as:

First pass lysine oxidation $=$ eqn $(9)-$ eqn $(8)$.

\section{REFERENCES}

1 Matthews DE, Marano MA, Campbell RG. Splanchnic bed utilization of leucine and phenylalanine in humans. Am J Physiol 1993:264:E109-18.

2 Hoerr RA, Matthews DE, Bier DM, et al. Leucine kinetics from $\left[{ }^{2} \mathrm{H}_{3}\right]$ - and $\left[{ }^{13} \mathrm{C}\right]$ leucine infused simultaneously by gut and vein. Am J Physiol 1991;260:E111-17.

3 Matthews DE, Motil KJ, Rohrbaugh DK, et al. Measurement of leucine metabolism in man from a primed, continuous infusion of $\mathrm{L}-\left[{ }^{13} \mathrm{C}\right]$ leucine. Am J Physiol 1980;238:E473-9.
4 Van der Schoor SRD, Van Goudoever JB, Henry JF, et al. The pattern of intestinal substrate oxidation is altered by protein restriction in pigs. Gastroenterology 2001;121:1167-75.

5 MacRae JC, Bruce LA, Brown DS, et al. Amino acid use by the gastrointestinal tract of sheep given lucerne forage. Am J Physiol 1997; 273:G1200-7.

6 Stoll B, Henry JF, Reeds PJ, et al. Catabolism dominates the first-pass intestinal metabolism of dietary essential amino acids in milk protein fed piglets. J Nutr 1998; 128:606-14.

7 Hoerr RA, Matthews DE, Bier DM, et al. Effects of protein restriction and acute refeeding on leucine and lysine kinetics in young men. Am J Physiol 1993;264:E567-75

8 Van Goudoever JB, Stoll B, Henry JF, et al. Adaptive regulation of intestinal lysine metabolism. Proc Nat Acad Sci U S A, 2000:97:11620-5.

9 Davis TA, Nguyen HV, Costa DP, et al. Amino acid composition of pinniped milk. Comp Biochem Physiol B Biochem Mol Biol 1995;110:633-9.

10 Moughan PJ, Birtles MJ, Cranwell PD, et al. The piglet as a model animal for studying aspects of digestion and absorption in milk-fed human infants. World Rev Nutr Diet 1992;67:40-113.

11 Wu G, Ott TL, Knabe DA, et al. Amino acid composition of the fetal pig. J Nutr 1999;129:1031-38.

12 Ball RO, House JD, Wykes $U$, et al. A piglet model for neonatal amino acid metabolism during TPN. In: Tumbleson ME, Schook LB, eds. Advances in swine in biomedical research. New York: Plenum Press, 1996:713-31

13 Metges CC, El-Khoury AE, Henneman L, et al. Availability of intestina microbial lysine for whole body lysine homeostasis in human subjects. Am J Physiol 1999;277:E597-607.

14 Stoll B, Burrin DG, Henry JF, et al. Substrate oxidation by the portal drained viscera of fed piglets. Am J Physiol 1999;277:E168-75.

15 Yu YM, Burke JF, Vogt JA, et al. Splanchnic and whole body L-

$\left[1-{ }^{13} \mathrm{C},{ }^{15} \mathrm{~N}\right]$ leucine kinetics in relation to enteral and parenteral amino acid supply. Am J Physiol 1992;262:E687-94.

16 Benevenga NJ, Radcliffe BC, Egan AR. Tissue metabolism of methionine in sheep. Aust J Biol Sci 1983;36:475-85.

17 Chu SH, Hegsted DM. Adaptive response of lysine and threonine degrading enzymes in adult rats. J Nutr 1976;106:1089-96.

18 Hutzler J, Dancis J. Lysine-ketoglutarate reductase in human tissues. Biochim Biophys Acta 1975;23:42-51.

19 Usher RH, McLean F. Intrauterine growth of live-born Caucasian infants at sea level: standards obtained from measurements in 7 dimensions of infants born between 25 and 44 weeks of gestation. J Pediatr 1969;74:901-10.

20 Rautonen J, Makela A, Boyd H, et al. CRIB and SNAP: assessing the risk of death for preterm neonates. Lancet 1994;343:1272-3.

21 Copeland KC, Kenney FA, Nair KS. Heated dorsal hand vein sampling for metabolic studies: a reappraisal. Am J Physiol 1992;263:E1010-14.

22 Perman JA, Barr RG, Watkins JB. Sucrose malabsorption in children; a noninvasive diagnosis by interval breath hydrogen determination. J Pediatr 1978;93:17-22.

23 Veereman-Wauters G, Ghoos Y, Van der Schoor S, et al. The ${ }^{13} \mathrm{C}$-octanoic acid breath test: a noninvasive technique to assess gastric emptying in preterm infants. J Pediatr Gastroenterol Nutr 1996:23:111-17.

24 Van Dijk-van Aalst K, Van den Driessche M, Van der Schoor S, et al. ${ }^{13} \mathrm{C}$ mixed triglyceride breath test: a noninvasive method to assess lipase activity in children. J Pediatr Gastroenterol Nutr 2001;32:579-85.

25 Husek P. Rapid derivatization and gas chromatographic determination of amino acids. J Chromatogr 1991;552:289-99.

26 Zuijdgeest-Van Leeuwen SD, Van den Berg JW, Wattimena JL, et al. Lipolysis and lipid oxidation in weight-losing cancer patients and healthy subjects. Metabolism 2000:49:931-6.

27 Steele R. Influence of glucose loading and of injected insulin on hepatic glucose output. Proc NY Acad Sci 1959;82:420-30

28 Tserng K, Hay WJ. Calculation of substrate turnover rate in stable isotope tracer studies. Am J Physiol 1983;245:E308-11.

29 Goldspink DF, Lewis SEM, Kelly FJ. Protein synthesis during developmental growth of the small and large intestine of the rat. Bioch J 1984;217:527-34.

30 Gaudichon C, Mahe S, Roos N, et al. Exogenous and endogenous nitrogen flow rates and level of protein hydrolysis in the human jejunum after $\left[{ }^{15} \mathrm{~N}\right]$ milk and [ $\left.{ }^{15} \mathrm{~N}\right]$ yoghurt ingestion. Br J Nutr 1995;74:251-60.

31 Shulman RJ, Gannon N, Reeds PJ. Cereal feeding and its impact on the nitrogen economy of the infant. Am J Clin Nutr 1995;62:969-72.

32 Shulman RJ, Henning, SJ, Nichols BL. The miniature pig as an anima model for the study of intestinal enzyme development. Pediatr Res 1988;23:311-15

33 Duffy B, Pencharz P. The effect of feeding route (IV or oral) on the protein metabolism of the neonate. Am J Clin Nutr 1986:43:108-11.

34 Lafeber HN. Are there beneficial effects of rapid introduction of enteral feeding in very low birth-weight infants, even in those with severe intrauterine growth retardation (IUGR)? J Pediatr Gastroenterol Nutr 2002;35:137-8.

35 Heim T. Homeothermy and its metabolic cost. In: Davis JA, Dobbing J, eds Scientific foundations of paediatrics. London: Heinemann, 1981:91-128.

36 Denne SC, Karn CK, Liu YM, et al. Effect of enteral versus parenteral feeding on leucine kinetics and fuel utilization in premature newborns. Pediatr Res 1994;36:429-35.

37 Van Goudoever JB, Sulkers EJ, Lafeber HN, et al. Short-term growth and substrate use in very-low-birth-weight infants fed formulas with different energy contents. Am J Clin Nutr 2000;71:816-21.

38 Van Goudoever JB, Sulkers EJ, Chapman TE, et al. Glucose kinetics and glucoregulatory hormone levels in ventilated, preterm infants on the first day of life. Pediatr Res 1993;33:553-9. 